\title{
Correction
}

\section{Correction to: From Global Value Chains (GVC) to Innovation Systems for Local Value Chains and Knowledge Creation}

Keun Lee ${ }^{\mathrm{a}, *}$, Marina Szapiro ${ }^{\mathrm{b}}$ and Zhuqing $\mathrm{Mao}^{\mathrm{a}}$

${ }^{a}$ Department of Economics, Seoul National University, Shillim Dong, Seoul 08826, Korea.

E-mail: mm7ng7ng@snu.ac.kr

${ }^{\mathrm{b}}$ Universidade Federal do Rio de Janeiro, Av. Pedro Calmon, 550 - Cidade Universitária, Rio De Janeiro, RJ 21941-901, Brazil.

E-mail: marina@ie.ufrj.br

*E-mail: kenneth@snu.ac.kr

The European Journal of Development Research (2018) 30, 575. https://doi.org/10.1057/s41287-0180160-5; published online 28 June 2018

\section{Correction to: Eur J Dev Res https://doi.org/10.1057/s41287-017-0111-6}

Unfortunately the wrong surname of the guest editor Sampath was inserted during the typesetting process. The correct name is Gehl Sampath.

We apologize for this error. 